Információközvetítés és közösségépítés - multifunkciós könyvtári hálózatok.

Szerk. Kiszl Péter, Németh Katalin. Budapest, ELTE BTK

Könyvtár- és Információtudományi Intézet. 2020. 237-246.

\title{
AZ ISKOLAI KÖNYVTÁR MINT HARMADIK HELY
}

\section{KÁMÁN VERONIKA}

\section{TARTALMI ÖSSZEFOGLALÓ}

Ray Oldenburg amerikai szociológus 1989-ben hozta be a köztudatba The great good place címü munkájával a harmadik hely fogalmát, amely három évtizede vitathatatlanul formálja a könyvtárakról és a könyvtárak önmagukról, szolgáltatásaikról, tereikről való gondolkodást egyaránt. Oldenburg álláspontja szerint az otthonunk („első hely”) és a munkahelyünk (jelen tanulmány értelmezése szerint az iskola - „második hely”) között, avagy ezeken túl létezik a „harmadik hely” mint mindezektől független közösségi tér: olyan nyilvános hely, amely otthont ad rendszeres, önkéntes, informális közösségi alkalmaknak. A tanulmány áttekinti, hogy az iskolai könyvtárak milyen értelemben definiálhatók harmadik helyként egy iskola szervezetében, s bemutatja, hogy ebből a speciális szempontból miképpen töltenek be helyettesíthetetlen szerepet az iskola egészének tanító-nevelő folyamatában.

„Ha sok cseresznyepaprikát madzagra füzünk, abból lesz a paprikakoszorú. Ha viszont nem füzzük fel őket, nem lesz belölük koszorú. Pedig a paprika ugyanannyi, éppoly piros, éppoly erös. De mégse koszorú. Csak a madzag tenné? Nem a madzag teszi. Az a madzag, mint tudjuk, mellékes, harmadrangú valami. Hát akkor mi? Aki ezen elgondolkozik, sügyel rá, hogy gondolatai ne kalandozzanak összevissza, hanem helyes irányban haladjanak, nagy igazságoknak jöhet a nyomára."

Örkény István ${ }^{1}$

\section{Bevezetés}

Amióta az eszemet tudom, a könyvtárak meghatározó terek az életemben; alapélményem, hogy a könyvtárakban otthon és biztonságban érzem magam. Egyet pedig biztosan tudtam a kezdetektől: a könyvtár nem pusztán könyvek tára. Láttam a szombathelyi megyei könyvtárban, hogy hogyan fordultak meg életek, hány embert segített a könyvtár éltető közege: nemcsak kutatókat, tanárokat kísért pályájukon, de életük vezetésében magányosakat, betegeket, otthontalanokat, csellengő fiatalokat, időseket ugyanígy. Az egyetemi évek alatt aztán arról tanultam, hogy a könyvtár forrásai révén elsősorban információt közvetít. Pályakezdőként az iskolai könyvtárak világába csöppenve pedig a börömön kezdtem tapasztalni: a könyvtár mint tér nemcsak a fizikai vagy a virtuális térben jelenlevő dokumentumokat engedheti olvasni, hanem egy 


\section{KÁMÁN VERONIKA}

olyan „könyvet” is, amelyet egy életen át olvasunk: önmagunkat. Az iskolai könyvtárba betérő, ott talán a „második otthonon” belüli otthont, (a szakirodalomban gyakran „safe haven”-ként, afféle menedékként emlegetett) biztonságos helyet kereső diákok (vagy tanárok) közül nem egy apránként az életét kezdi megosztani a könyvtárossal, aki - különösen ezekben a pillanatokban - nem klasszikus tanári szerepben van jelen, hanem elsősorban felnőttként, s ilyen értelemben segítő szerepben találja magát. Ugyanígy a könyvtár tere sem egy hagyományos iskolai tér: más szabályok érvényesek itt, mint például egy tanteremben vagy a folyosón - a kötetlen atmoszféra, az egyenlőség, a nyitottság és hozzáférhetőség „harmadik hellyé” teszi a könyvtárat, valahol félúton az otthon és hagyományos iskolai terek között.

Jelen tanulmány célja, hogy röviden áttekintse, az iskolai könyvtárak milyen értelemben definiálhatók harmadik helyként egy iskola szervezetében (erről kevés magyar nyelvü irodalom áll rendelkezésre), s felvillantsa, hogy ebből a speciális szempontból miért is nélkülözhetetlen egy teljes értékű iskolai folyamatban az iskolai könyvtárak léte.

\section{Könyvtár az iskolában - funkciók, feladatok, felelősségek}

Amikor áttekintjük az utóbbi két évtizedben született nemzetközi irányadó dokumentumokat, útmutatókat, amelyek az iskolai könyvtárak működésével kapcsolatban tesznek ajánlásokat, számos, alapvetően egybevágó definícióval találkozunk. A Könyvtári Egyesületek és Szervezetek Nemzetközi Szövetsége (International Federation of Library Associations and Institutions - IFLA) és az Egyesült Nemzetek Nevelésügyi, Tudományos és Kulturális Szervezete (United Nations Educational, Scientific and Cultural Organization - UNESCO) 1999-ben napvilágot látott közös nyilatkozata úgy határozta meg az ezredfordulón az iskolai könyvtárat, mint a tanítás és a tanulás színhelyét mindenki számára. ${ }^{2}$ Amikor pedig az iskolai könyvtári szolgáltatások feladatairól olvasunk, szervező elvként az oktatási folyamatba való integráltság jelenik meg. Az iskolai könyvtár együttműködik „a tanulókkal, a tanárokkal, az iskolavezetéssel és a szülőkkel” a pedagógiai program és a helyi tanterv célkitűzéseinek megvalósításáért ${ }^{3}$, a diákokkal az autonóm információszerzés és a kritikus gondolkodás kialakításáért. Mindemellett nélkülözhetetlen partnert jelent a „helyi, a regionális és az országos könyvtári és információs hálózat”4 számára is. A dokumentum egyes célkitüzéseiben azonban megcsillan a klasszikusnak mondható könyvtári, iskolai könyvtári funkciókon túl néhány „nem hagyományos” szempont, mint a kulturális és társadalmi tudatosság fejlesztése, valamint a személyiség- és érzékenységfejlesztés szempontja. ${ }^{5}$

Tóth Gyula a Könyvtárosok kézikönyve iskolai könyvtárakról szóló fejezetében arra világít rá, hogy az iskolai könyvtár fejlődése során fokozatosan „eltávolodott a köz(müvelödési) (gyermek)könyvtári vonásoktól”, és „az iskolában folyó sokrétü munka eszközévé, helyileg is elválaszthatatlan munkakönyvtárrá vált”. ${ }^{6}$ Igy ír: „Itt 
már nem egy iskolában elhelyezett valamiféle könyvtárról van szó, hanem maga az iskola vonult be a könyvtárba, integrálta önmaga szervezetébe és tevékenységébe. Az iskola más tereihez hasonlóan a könyvtár sajátos szolgáltatásaival az ismeretszerzés, vagyis a tanulás és nevelés színterévé és eszközévé vált."’

A nemzetközi irányelvek legaktuálisabb darabja már egy gyökeresen megújult iskolaikönyvtár-képet tár az olvasó elé, miközben fő céljának továbbra is az IFLA és az UNESCO közös könyvtári nyilatkozatának alapcélkitüzését tartja. Az IFLA Iskolai könyvtári útmutató második, átdolgozott kiadása, amely 2015 júniusában, magyarul 2016 novemberében látott napvilágot, úgy definiálja az iskolai könyvtárat, mint egy fizikai és digitális tanulási helyet az iskolában, „ahol az olvasás, kérdezés, kutatás, gondolkodás, képzelőerő és a kreativitás központi fontosságú a diákoknak az információktól a tudásig tartó »utazásához« és a személyes, társadalmi és kulturális fejlődéséhez". ${ }^{8} \mathrm{Ez}$ az iránymutatás azt mondja, önmagában még nem elegendö, ha az iskolai könyvtár pusztán csak megfelel „a költségvetésre, a technikára, a gyüjteményre, személyzetre és tárgyi eszközökre" vonatkozó szabályoknak. Mivel a dokumentum az iskolai könyvtárat minden korábbinál jobban az iskola közösségének integráns részeként látja, úgy fogalmaz, hogy a puszta szabálykövetésnél sokkal fontosabb, hogy az iskola mint közösség miképpen gondolkodik az iskolai könyvtárról, amely „morális célokért dolgozik (azaz [hogy] változást hozzon a fiatalok életébe) és oktatási célokért dolgozik (azaz javítja az oktatást és a tanulást)" ${ }^{\prime \prime}$. Az útmutató szemlélete szerint a felszerelés, az állomány, a technológia, és valójában a könyvtár munkatársai mind-mind „eszközök” az iskola és a könyvtár céljainak megvalósításában.

\section{A harmadik hely fogalma}

Ray Oldenburg amerikai szociológus elsőként 1989-ben megjelent The great good place címü munkájával egy olyan új fogalmat teremtett meg és hozott a köztudatba, amely három évtizede vitathatatlanul formálja a könyvtárakról és a könyvtárak önmagukról, szolgáltatásaikról, tereikről való gondolkodást egyaránt. Oldenburg álláspontja szerint az otthonunk („első hely”) és a munkahelyünk (jelen tanulmány értelmezése szerint az iskola - „második hely”) között, avagy ezeken túl létezik a „harmadik hely” mint mindezektől független közösségi tér: olyan nyilvános hely, amely otthont ad rendszeres, önkéntes, informális közösségi alkalmaknak, amelyeken a résztvevők szívesen jelennek meg - túl az otthoni és a munkahelyi tevékenységeken. ${ }^{10}$ Oldenburg nyolc jellemzővel ragadja meg a harmadik helyek sajátosságait, amelyeket itt Pete Myers összefoglalója alapján ismertetünk ${ }^{11}$ :

- semleges terep: nyilvános, kényelmes, szabadon hozzáférhető tér, amelyben nem kötelező jelen lenni, de amely elösegíti a közösség kialakulását, fejlődését;

- „kiegyenlitô” hely: amely elősegíti a közösséget, felülemelkedve a gazdasági vagy társadalmi státusz okozta megosztottságon, ahol a kölcsönös elfogadás 


\section{KÁMÁN VERONIKA}

formális követelményei minimálisra csökkennek (vagy ideálisan: nincsenek ilyenek);

- egy hely, ahol lehet beszélgetni: mégpedig jó kedéllyel, humorral, könnyü szívvel; ahol megengedhetjük, hogy ez legyen az első, de nem szükségszerüen egyetlen funkció;

- nyitott, hozzáférhető hely: amelyet következmények nélkül használhatunk hosszú órákon keresztül különösebb előzetes tervezettség nélkül, amely kényelmes és válaszol a használók különféle igényeire;

- ahol vannak törzsvendégek: az ő szerepük elengedhetetlen, mert mintegy életben tartják a közösségi teret, meghatározzák annak atmoszféráját, hangulatát - sőt befogadják az újonnan érkezőket, bevezetik őket és megismertetik velük a hely sajátosságait;

- ahol a hangulat játékos: van helye a humornak, az évődésnek, sőt ezeknek értékük van a közösség számára: Myers megállapítása szerint a harmadik helyet voltaképpen az általa ösztönzött „,ezt folytassuk máskor is” magatartása élteti;

- amely végső soron egy otthon távol az otthontól: ahol a betérő megélheti a melegséget, intimitást, a valahova tartozás örömét.

Oldenburg munkájában szélesre tárja a harmadik helyek körét, közéjük sorolva a kávéházaktól kezdve a szépségszalonokon és kocsmákon át a postahivatalokat, a borbélyüzleteket és a sétálóutcákat is, de Kuno Kazuko 2011-ben megjelent tanulmányának megállapítása szerint sem ebben a könyvben, sem az ezt követően publikált Celebrating the third place címü kötetben nem sorolja a harmadik helyek körébe a könyvtárakat. ${ }^{12}$ Kawasakit idézve Kuno Kazuko úgy véli, talán a fenti kritériumok közül a beszélgetés korlátozott lehetősége távolítja el Oldenburgot attól, hogy a könyvtárakat is harmadik helynek tekintse. ${ }^{13}$

\section{A könyvtár mint harmadik hely}

Számot kell vetnünk azzal, hogy a harmadik hely koncepciója a nyolcvanas évek végén egy, a maitól meröben eltérő könyvtárkép jellemezte korszakban született. Robert Barth svájci kutató - elsősorban a tudományos és szakkönyvtárakra vonatkozó - megállapítása szerint ugyanis az 1970-es években a könyvtárak még a csend és a tudás mentsvárai voltak - rövid nyitvatartási idővel és nemegyszer inkább csak a kölcsönzésre összpontosítva -, és nem nagyon marasztalták a felhasználókat. Ahogy azonban az internet mind erősebb térhódításával megváltozott a könyvtárak korábbi „monopolhelyzete”, új szolgáltatások kiépítésére lett szükség. Barth úgy látja, a XXI. századra a könyvtárak egyre nagyobb hangsúlyt fektetnek az ott eltöltött időre: a puszta dokumentumgyüjtemények helyett egyszerre információs centrumok és tanulási terek, amelyek nemcsak az elmélyült egyéni munkára, de a csoportmunkához is teret kell, 
hogy biztosítsanak, mindezt a koncentrációt segítő, motiváló környezettel és megfelelő technikai felszereltséggel támogatva meg. ${ }^{14}$

Barth felhívja a figyelmet arra is, hogy a könyvtár nem pusztán a tanulás vagy a kutatás tere, hanem közösségi tér is. Kiemeli: számot kell vetnünk azzal, hogy egyre növekszik az egyedül élők száma, s számukra a könyvtár ideális tér a másokkal való találkozásra, ahol személyes érdeklődési körüknek megfelelően juthatnak információkhoz, bővíthetik ismereteiket anélkül, hogy ez anyagi terhet jelentene számukra. Hasonlóképp fontosnak látja a fiatalok megszólítását is, amelyre a megoldást elsősorban a technológiai felkészültségben látja. ${ }^{15} \mathrm{Az}$ IFLA Iskolai könyvtári útmutatójának korábban már idézett átdolgozott kiadása épp abban az évben, amikor Barth cikke is megjelenik, úgy látja, a közösségi média nyomán egyre meghatározóbbá váló „részvételi kultúra” a könyvtárhasználók szerepét is kiterjeszti „az információ fogyasztójától az információ létrehozásáig”. Az iránymutatás így nem pusztán a megszólítás eszközét látja a technológiai vívmányokban, hanem arra bátorítja az iskolai könyvtárakat, hogy hozzanak létre ún. „alkotói tereket” (makerspace), ahol „számítógépek és egyéb digitális eszközök segítségével gyakorlati feladatokat tudnak végrehajtani, ideértve információs termékek (pl. videók, blogok, podkasztok, 3D-projektek, poszterek, infografikák) előállítását is" ${ }^{16}$

A könyvtár mint harmadik hely kérdésköre a 2000-es évek közepétől jelenik meg a nemzetközi szakirodalomban, magyarul pedig 2010-ben, Szóllás Péter tollából olvashatott az elméletről a szakma, amikor a Könyv, Könyvtár, Könyvtáros hasábjain megjelent $A$ könyvtár mint harmadik hely címü tanulmánya. ${ }^{17} \mathrm{~A}$ szerző így alkalmazza a harmadik hely „kritériumait” a könyvtárakra: a könyvtár „nemcsak a felnőtteknek való, hanem a fiatalokért is van, összehozza a különböző korú és érdeklődésű embereket. Befogadó, közösségteremtö légkört találunk itt, ahol megpihenhetünk a munka vagy az iskola után. Elősegíti a társadalomba való beilleszkedést, ami nagyon fontos lehet azoknak, akik hátrányos helyzetüek, vagy akik messziről érkeztek. Ez a hely találkozási pont, amelyet a környéken mindenki ismer". ${ }^{18}$

\section{Az iskolai könyvtár mint harmadik hely}

Kuno Kazuko már idézett tanulmányában a fenti pontokat sorra véve vizsgálja az iskolai könyvtárak harmadik hely jellegét, rámutatva a harmadik helyek jótékony hatásaira személyes és közösségi szempontból egyaránt. A személyre gyakorolt jótékony hatások között emeli ki, hogy a harmadik helyek (s így az iskolai könyvtárak is) terei az örömnek, az életvidámságnak, az elfogadásnak, és fejlesztik az egyén olyan készségeit, mint a civil tudatosság, a demokratikus érzék, az önbizalom, a valahová tartozás érzése. A közösségi aspektust említve a szerző azt emeli ki - Oldenburg nyomán -, hogy a harmadik helyek (s így az iskolai könyvtárak is) alkalmas teret jelentenek a generációk közötti találkozásoknak, összehozzák a fiatalokat és felnőtteket, a diákokat és a tanárokat. ${ }^{19}$ 


\section{KÁMÁN VERONIKA}

Az, hogy a könyvtárak harmadik helynek tekinthetők, már önmagában is innovatív felismerés, de hogy ugyanezt az iskolai könyvtárakra is vonatkoztathatjuk, még speciálisabb és még inkább újszerü szempont. Az iskolai könyvtár mint közösségi tér, mint „harmadik hely” nem olyan közeg, amely elszigetelten müködne az iskola tereitől, pedagógiai programjától, napi tevékenységétől, oktatási-nevelési céljaitól. A benne zajló, a harmadik helyekre jellemző közösségi tevékenységek számára az ott müködő könyvtárpedagógiai támogató munka ad hátteret, amelyet elsősorban az iskola pedagógiai programja és a könyvtárpedagógiai program szabályoz. A Barátné Hajdu Ágnes által jegyzett, 2015-ben megjelent Bevezetés a könyvtárhasználati ismeretek oktatásába címü munka melléklete bemutat néhány mintaszerü könyvtárpedagógiai programot. A Veres Pálné Gimnázium Ugrin Gáborné könyvtárának programja - megfogalmazva tevékenységének céljait - első helyen említi a következőt: „A könyvtár közösségi térré kell váljon, ahol a kulturált szabadidős tevékenységeknek, az önmüvelésnek, az információs források használatának éppúgy helye van, mint az előadásoknak, konferenciáknak, megbeszéléseknek. Mindez csak a könyvtárhasználati nevelő-oktató munka mellett képzelhető el, s azt nem hátráltathatja." ${ }^{20} \mathrm{Az}$ iskolai könyvtár tehát nemcsak helyet ad ezeknek a tevékenységeknek, de a könyvtári gyűjtemény gazdagságával és a hozzáadott pedagógiai munkával motiválja is azok müködését. (Gondolhatunk például egy, az iskolai könyvtárban rendezett gimnáziumi vitakörre, ahol a vitázás hevében a résztvevők a könyvtárostanár támogatásával megbízható, hasznos információforrásokhoz nyúlhatnak.) Valóban: a harmadik helyek jellemzői nemcsak az iskolai könyvtárhoz kötődő közösségi tevékenységekben mutatkoznak meg, de az ott zajló sajátos tanulási folyamatban is. Martin Gray, ausztrál könyvtárostanár rámutat: az iskolai könyvtár nem osztályterem és nem játszótér, mégis mindkettő jellemzőit magában hordozza: alkalmas teret kínál a kikapcsolódásra, a pihenésre, a tanulást pedig úgy teszi lehetővé, mint egy önmagát irányító, a diák saját erőire és egyéni érdeklődésére támaszkodó folyamatot, amely akkor és úgy zajlik, amikor és ahogy ezt a diák akarja. ${ }^{21}$

\section{Az iskolai könyvtár mint harmadik hely jellemzöi}

De pontosan mi tesz egy iskolai könyvtárat harmadik hellyé? Doug Johnson amerikai könyvtárostanár 2010-ben született blogbejegyzése ad inspirációt, hogy átgondoljunk néhány ezzel kapcsolatos szempontot. ${ }^{22}$

- Az iskolai könyvtár olyan tér, amelyben egyszerre lehetséges az egyéni, elmélyült munka, de ugyanakkor helye a felszabadult közösségi tevékenységnek is (közös projektek kidolgozása, megbeszélések, közös játék, közös ünneplés).

- Ezeknek a tevékenységeknek nemcsak a könyvtár fizikai tere ad otthont, de virtuálissá is bővülhet (Skype-konferenciák nemzetközi projektekben, közösségi játékok vagy együttmüködési projektek az online térben stb.). 
- Mindezekhez az iskolai könyvtárban megfelelő technikai felszereltség áll rendelkezésre (számítógépek, laptopok, az online kapcsolatfelvételhez szükséges eszközök stb.).

- A könyvtár gyüjteménye nemcsak a tanórákra való felkészüléshez kapcsolódó dokumentumokból, kötelező olvasmányokból stb. épül fel, hanem elérhető az igényes szórakoztató irodalom, ifúsági irodalom, filmek, magazinok, az önfejlesztést, önmegismerést segítő kiadványok lehetőleg széles választéka mind a diákok, mind a tanárok számára.

- A gyüjtemény megismerését tematikus ajánlópolcok segíthetik (nemcsak a „klasszikus” tantárgyi témákban, hanem a felhasználókat [elsősorban a tizenéveseket] legégetőbben érintő területeken - mint pl. az önismeret, önkép; diákmunka; klímaváltozás; függőségek stb.).

- A munkához és a pihenéshez egyaránt kényelmes, barátságos (munka)környezet áll rendelkezésre. Ez magában foglalja az alakítható, tágas, átrendezhető könyvtári tereket; munkaasztalokat és székeket; babzsákokat, foteleket; csendes, magányos elvonulásra vagy négyszemközti beszélgetésre is alkalmas zugokat (amelyekben egy iskola gyakran hiányt szenved); a lehetöséget a csendes és a zajos tevékenységek egymástól való elválasztására; a megfelelő világítást és a friss levegöt.

- Az iskolai könyvtár tereivel, gyüjteményével, technikai felszereltségével az iskola minden polgára - diákok, tanárok, munkatársak, szülők - számára nyitott tér, amely ehhez megfelelően stabil és hosszú nyitvatartási időt biztosít.

- Nyitottsága pedig nemcsak térben és időben valósul meg: ingyenesen látogatható és szolgáltatásai is ingyenesek. Ahogy Szóllás Péter is felhívja erre cikkében a figyelmet ${ }^{23}$, a nyilvános könyvtárak esetében ez eleve megvalósul az 1997. évi CXL. törvény szabályozásából adódóan, amely elöírja, hogy a könyvtárhasználók jogosultak bármely nyilvános könyvtár szolgáltatásainak igénybevételére, s a használót a törvényben foglalt alapszolgáltatások ingyenesen illetik meg. ${ }^{24}$ Ugyanez az ingyenesség az iskolai könyvtárak esetében is adott, ahol a felhasználók körét elsősorban az iskola polgárai alkotják.

Az itt leírt szolgáltatások, lehetőségek megvalósulása természetesen kitágítja a hagyományos iskolaikönyvtár-képet, és a könyvtár munkatársaitól is kellő rugalmasságot, nagyfokú támogatást kíván. Doug Johnson szavaival élve szükség van egy olyan térre az iskolán belül is, ahol diákok eltölthetik a szabadidejüket, ahol tere van a „zajos munkának" és a tantárgyi keretektől eltérő személyes érdeklődés is támogatásra lel.

Az iskolai könyvtár mint biztonságos hely

A személyre irányuló támogatás azonban nem állhat meg a tantárgyi érdeklődésnél. Ha ugyanis az iskolai könyvtár életre szóló és életalakító szerepbe akarja helyezni a tudást a fiatalok számára, akkor már nem maradhat kizárólag tudásközpontú - hi- 


\section{KÁMÁN VERONIKA}

szen a fiatalok kérdései nemcsak az ismeretekre vonatkoznak. Ahogy az IFLA Iskolai könyvtári útmutatója is kijelenti: „A diákoknak olyan helyzetekben is otthonosan kell mozogniuk, amikor több válasz is lehetséges, és akkor is, amikor nincsen válasz." ${ }^{25} \mathrm{Az}$ iskolai könyvtár olyan térré válhat, ahol a diákok megtapasztalják, hogy elfogadják és meghallgatják őket. Melissa Johnston és Wade Bishop tanulmányukban - amely az iskolai könyvtárat mint helyet vizsgálja - több szakértőt idézve hangsúlyozzák: az iskolai könyvtár - amelynek légkörében olyan értékeknek kell uralkodniuk, mint a kölcsönös tisztelet, az elfogadás, a tolerancia és a biztonság - különösen lényeges tér azoknak a diákoknak, akik valamiképpen izolálódtak saját iskolai közösségükben, és szükségük van arra, hogy megtapasztalják az elfogadást és a valahová tartozás élményét. ${ }^{26}$ Ennek megvalósulásában a könyvtárostanár kulcsszerepet játszik.

A könyvtárak - ideértve az iskolai könyvtárakat is - biztonságos helyet kínálhatnak azon fiatalok számára is, akik különösen erős rászorultságot élnek át. Az ENSZ által meghirdetett ifúsági világnap témája 2018-ban a fiatalok számára felkínált biztonságos helyek voltak. Az IFLA erre a napra, 2018. augusztus 12-ére megjelentetett dokumentuma azt vizsgálta, hogy miképpen jelenthetnek a könyvtárak biztonságos teret, egyfajta menedéket a tizenévesek számára, gondolva elsősorban azokra a fiatalokra, akik valamilyen szempontból - hátterük, hovatartozásuk, körülményeik okán a társadalom peremén rekedtek, és nagyobb veszélynek vannak kitéve a szerencsésebb körülmények közül érkező társaiknál. Az IFLA kijelenti: a könyvtárak alkalmas terek arra, hogy a gyermekkor és a felnőttkor közötti igen érzékeny átmeneti időszakban biztos menedéket nyújtsanak a fiataloknak, akik a könyvtárakban (legyenek ezek közművelődési vagy iskolai könyvtárak) fejleszthetik készségeiket, képességeiket, utánajárhatnak elgondolásaiknak. ${ }^{27}$

\section{Kitekintés}

Az iskolai könyvtárak mint harmadik helyek kérdéskörének vizsgálata nyomán világossá válik: a további gondolkodás, kutatás lehetőségei sokrétüek.

Beláttuk, hogy az iskolai könyvtár terei, szolgáltatásai, működésének jellegzetességei révén a harmadik helyek körébe sorolható, ám az is világos, hogy mindazok a tulajdonságok, amelyek harmadik hellyé teszik (és maga az iskolai könyvtár), nem izoláltan, az iskola egészének müködésétől függetlenül vannak jelen. Fontos kérdés, hogy milyen módon kötődhetnek az iskolai könyvtár itt feltárt támogató szerepei az iskola többi egységének, elsősorban a nem közvetlenül a tanítással, neveléssel foglalkozó egységeinek tevékenységeihez (mint a gyermekvédelem, az iskolapszichológia, a diákönkormányzat, a közösségi szolgálatok szervezése stb.), hogyan válhatnak aktivitásuk révén egymást kiegészítő, sőt egymás támogató tevékenységét felerősítő terekké? Hogyan illeszthető be tudatosan az iskolai könyvtár léte és tevékenysége ebből a speciális szempontból az iskola nagyobb rendszerébe, pedagógiai programjába? Meddig tart 
mindebben a könyvtárostanár feladata, felelőssége és kompetenciahatárai? Különösen égetőek lehetnek ezek a kérdések, ha számot vetünk a gyakran egyre nehezebb családi háttérhelyzetekből érkező diákok valóságával, akik az iskolában nemcsak tanulási teret, de támogató környezetet, sőt afféle második otthont is keresnek.

\section{Irodalom és jegyzetek}

1. ÖRKÉNY István: Az élet értelme. In: Örkény István: Egyperces novellák. Budapest, Palatinus Kiadó, 2008. 522. p.

2. Az IFLA és az UNESCO közös könyvtári nyilatkozata. IFLA-UNESCO, 1999. Forrás: https://www.ifla.org/files/assets/school-libraries-resource-centers/publications/schoollibrary-manifesto-hu.pdf [2019. május 27.] 1. p.

3. Uo. 2. p.

4. Uo. 1.p.

5. Uo. 2. p.

6. TÓTH Gyula: Az iskolai könyvtár. In: Horváth Tibor - Papp István (szerk.): Könyvtárosok kézikönyve 3. A könyvtárak rendszere. Budapest, Osiris Kiadó, 2003. 163. p.

7. Uo.

8. SCHULTZ-JONES, Barbara - OBERG, Dianne (szerk.): IFLA Iskolai könyvtári útmutató. 2. átd. kiad. Budapest, Könyvtárostanárok Egyesülete, 2016. 15. p.

9. Uo. 12. p.

10. OLDENBURG, Ray: The great good place: cafes, coffee shops, bookstores, bars, hair salons and other hangouts at the heart of a community. Boston, Da Capo Press, 1999. 16. p.

11. MEYERS, Pete (ed.): Going home. Essays, articles, and stories in honour of the Andersons. London, Oak Hill College, 2012. 37. p. Idézi: KUNO, Kazuko: School libraries as the "third place". = Lifelong Education and Libraries, 2011. 11. no. 111. p. Forrás: https:// repository.kulib.kyoto-u.ac.jp/dspace/bitstream/2433/152088/1/lel11_109.pdf [2019. május 27.]

12. KUNO, Kazuko: School libraries as the "third place". = Lifelong Education and Libraries, 2011. 11. no. 111. p. Forrás: https://repository.kulib.kyoto-u.ac.jp/dspace/bitstream/ 2433/152088/1/lel11_109.pdf [2019. május 27.]

13. Uo.

14. BARTH, Robert: Die Bibliothek als Dritter Ort. = Buch und Bibliothek, 67. Jg. 7. H. 2015. 426. p.

15. Uo. 427. p.

16. SCHULTZ-JONES, Barbara - OBERG, Dianne (szerk.): i. m. 37. p.

17. SZÓLLÁS Péter: A könyvtár mint harmadik hely. = Könyv, Könyvtár, Könyvtáros, 19. évf. 11. sz. 2010. 3-7. p. Forrás: http://epa.oszk.hu/01300/01367/00237/pdf/EPA01367_3K_ 2010_11_03-07.pdf [2019. május 27.]

18. Uo. 3. p. 


\section{KÁMÁN VERONIKA}

19. KUNO, Kazuko: School libraries as the "third place". = Lifelong Education and Libraries, 11. no. 2011. 111-112. p. Forrás: https://repository.kulib.kyoto-u.ac.jp/dspace/bitstream/2433/152088/1/lel11_109.pdf [2019. május 27.]

20. BARÁTNÉ HAJDU Ágnes: Bevezetés a könyvtárhasználati ismeretek oktatásába. Budapest, Eötvös Loránd Tudományegyetem, 2015. 83. p.

21. GRAY, Martin: School libraries as the third place. = Access, 31. vol. 2017. 4. no. 36. p.

22. JOHNSON, Doug: School libraries as a "third place" = Doug Johnson weboldala, 2011. június 14. Forrás: http://dougjohnson.squarespace.com/dougwri/school-libraries-as-athird-place.html [2019. május 27.]

23. SZÓLLÁS Péter: i. m. 3-7. p.

24. 1997. évi CXL. törvény a muzeális intézményekről, a nyilvános könyvtári ellátásról és a közmüvelődésről. Forrás: https://net.jogtar.hu/jr/gen/hjegy_doc.cgi?docid=99700140.TV [2019. május 28.]

25. SCHULTZ-JONES, Barbara - OBERG, Dianne (szerk.): i. m. 44. p.

26. JOHNSTON, Melissa P. - BISHOP, Bradley B.: The potential and possibilities for utlizing geographic information systems to inform school library as place. $=$ School Libraries Worldwide, 17. vol. 2011. 1. no. 3-4. p.

27. How libraries provide safe spaces for (all) youth. IFLA, 2018. augusztus 12. 1. p. Forrás: https://www.ifla.org/files/assets/hq/topics/libraries-development/documents/how_ libraries_provide_safe_spaces_to_all_youth.pdf [2019. június 3.]

Kámán Veronika 2010-ben végzett az ELTE BTK informatikus könyvtáros mesterképzésén, üzleti információmenedzser specializáción. Jelenleg az Óbudai Árpád Gimnázium könyvtárosa, 2012 és 2018 között a Könyvtárostanárok Egyesülete elnökségi tagja, az egyesület nemzetközi kapcsolatainak felelőse. 